\title{
The effect of different bioregulators on lateral shoot formation in maiden apple trees
}

\author{
Maciej Gąstol ${ }^{1 *}$, Iwona Domagala-Świątkiewicz ${ }^{2}$, Michat Bijak ${ }^{2}$ \\ ${ }^{1}$ Department of Pomology and Apiculture \\ ${ }^{2}$ Department of Soil Cultivation and Fertilisation \\ University of Agriculture in Krakow \\ 29 Listopada 54, 31-425 Kraków, Poland
}

\begin{abstract}
One-year-old Malus domestica Borkh. 'Boskoop' and 'Mutsu' nursery trees on M.9 rootstock were treated with foliar sprays of different $\mathrm{BA}+\mathrm{GA}_{3}$ mixtures $\left(450+450 \mathrm{mg} \mathrm{dm}^{-3}\right.$ or $\left.780+120 \mathrm{mg} \mathrm{dm}{ }^{-3}\right)$ or BA $+\mathrm{GA}_{4+7}$ combinations $\left(450+450\right.$ or $\left.330+570 \mathrm{mg} \mathrm{dm}^{-3}\right)$. Both cultivars showed strong apical dominance; however, increased branching potential was observed following the use of exogenous growth regulators. All of the investigated branching agents revealed a high effectiveness, yet only after one treatment. Environmental factors played a major role in the induction of sylleptic shoot formation, especially in the case of 'Boskoop'. In the case of 'Boskoop', the branching effect was correlated with several vegetative growth properties (tree height, trunk diameter), while for 'Mutsu', a different branching pattern was found with no correlations ascertained. No tree injuries were observed following the use of a chemical branching agent.
\end{abstract}

Key words: branching, Malus domestica, nursery, plant growth regulators, tree quality

\section{Abbreviations:}

BA - 6-Benzylaminopurine, syn: benzyladenine; GA - Gibberellic acid; a.i. - active ingredient

\section{INTRODUCTION}

The use of strong, well-branched nursery trees greatly contributes to early and abundant orchard cropping (van Oosten 1983, Bielicki et al. 2003). However, a lack or insufficient number of laterals required to form proper tree crowns is a limitation in nursery production. The branching of maiden trees may be influenced by cultural practices such as: rootstock used, propagation techniques, plant density, fertilisation as well as the climate (Wilson and Jarassamrit 1993, Tromp 1996). However, the ultimate factor responsible for poor feathering is a strong apical dominance (Abbas 1978), which is under genetic control. The phenomenon of apical dominance is though to be controlled by the interaction of endogenous growth hormones, especially auxins and gibberellins. The easiest method to overcome the dominance is to mechanically remove the auxin source (heading), disturb their transport (leader twisting) or change the nutritional equilibrium between leaves and lateral buds (top leaf removal). However, all of these physical methods are thought to be less effective than the application of chemicals (Gastor 
and Poniedziałek 2003), as they promote only a few uppermost buds to develop into vigorous laterals (Ferree 1981). The chemical stimulation of branching may be achieved by the application of benzyladenine (BA) alone (Edgerton 1983, Basak et al. 1993, Hrotko et al. 1998). In addition, BA and $\mathrm{GA}_{3}$ mixtures efficiently depress apical dominance and induce feathering (Jaumień et al. 1993, Gąstoł and Poniedziałek 2003). The most commonly used branching agent, Promalin, is a mixture of benzyladenine and gibberellins $\left(\mathrm{GA}_{4+7}\right)$ (Joustra 1989, Rossi et al. 2004). However, the response of the cultivar to chemicals differs from one to another, especially as some of them show negative effects (growth retard, phytotoxicity effects). To know the rate, timing, and combination of cytokinins, gibberellins and additional substances is crucial for the best nursery production. Thus, many experiments on bioregulator form, their concentration, composition as well as number of treatments have been conducted in many countries (Jacyna 1996, Theron et al. 2000, Magyar and Hrotko 2005, Çaglar and Mürüvvet 2009).

The purpose of this experiment was to compare different mixtures of $\mathrm{BA}+\mathrm{GA}_{3}$ or $\mathrm{BA}+\mathrm{GA}_{4+7}$ with/ without additives in promoting lateral branching in young nursery apple trees.

\section{MATERIAL AND METHODS}

\section{Experimental site}

The experiment was conducted in the years 20082009 in the nursery located in Usarzów, near Sandomierz, Poland. Trees of two difficult-to-branch apple cultivars, 'Boskoop' and 'Mutsu', were used for this study. All of them were budded on standard M.9 rootstock. Tree spacing was $90 \mathrm{~cm}$ between rows and $30 \mathrm{~cm}$ in-row. In the nursery routine, pest and weed control programs were applied.

\section{Experimental design}

The treatments were:

1. Control trees,

2. NeoArbolin $\left(1.8 \% \mathrm{BA}+1.8 \% \mathrm{GA}_{4+7}\right)-$ sprayed $25.0 \mathrm{ml} \mathrm{dm}^{-3}(450 \mathrm{mg} \mathrm{BA}+450 \mathrm{mg}$ $\mathrm{GA}_{4+7}$ per $\mathrm{dm}^{3}$ ),
3. NeoArbolin Extra $\left(3.3 \% \mathrm{BA}+5.7 \% \mathrm{GA}_{4+7}\right)$ - sprayed $10.0 \mathrm{ml} \mathrm{dm}^{-3}(330 \mathrm{mg} \mathrm{BA}+570$ $\mathrm{mg} \mathrm{GA}_{4+7}$ per $\left.\mathrm{dm}^{3}\right)$,

4. Arbolin Extra 038SL (3.3\% BA $\left.+0.5 \% \mathrm{GA}_{3}\right)$ - sprayed $23.7 \mathrm{ml} \mathrm{dm}^{-3}(780 \mathrm{mg} \mathrm{BA}+120 \mathrm{mg}$ $\mathrm{GA}_{3}$ per $\left.\mathrm{dm}^{3}\right)$,

5. Arbolin $036 \mathrm{SL}\left(1.8 \% \mathrm{BA}+1.8 \% \mathrm{GA}_{3}\right)-$ sprayed $25.0 \mathrm{ml} \mathrm{dm}^{-3}(450 \mathrm{mg} \mathrm{BA}+450 \mathrm{mg}$ $\mathrm{GA}_{3}$ per $\mathrm{dm}^{3}$ ).

The experimental design was a complete randomised design with 20 trees per plot and four replications. All of the chemicals used were mixtures of cytokinin benzyladenine and gibberellins. However, different additives were used during formulation. In Arbolin Extra 38SL, a special kind of plant glue was added, whereas NeoArbolin and NeoArbolin Extra contained extra amino acids. Arbolin 036SL had no additives. Only a single application of plant growth regulators was performed. For each chemical treatment, the wetting agent Adpros $850 \mathrm{SL}\left(5 \mathrm{ml} \mathrm{dm}^{-3}\right)$ was added. The control trees were only sprayed with a water solution of Adpros 850SL. The chemicals were applied at the end of June, when the tree height was approximately $70-75 \mathrm{~cm}$. At the time of treatment, the trees had no branches.

The following measurements were made:

Tree height and trunk diameter $(10 \mathrm{~cm}$ beyond and under the graft) were measured before the harvest in October. Trees that had three or more laterals were considered to be feathered and their quantity was expressed as a percentage of total number per treatment. In addition, the total number of laterals was counted, and the length of shoots $(>15 \mathrm{~cm})$ was measured.

\section{Soil and climatic conditions}

Soil samples were collected from the fruit nursery in September 2007. According to the Polish norm (BN-178/9180-11), particle-size distribution indicated silty loam to silty clay soil texture. The total organic matter in the analysed soils ranged between $1.46 \%$ in the $20-40 \mathrm{~cm}$ layer to $1.73 \%$ in the $0-20 \mathrm{~cm}$ layer. Soil $\mathrm{pH}$ values measured in

Table 1. Acid reaction $(\mathrm{pH}), \mathrm{EC}\left(\mu \mathrm{S} \mathrm{cm} \mathrm{c}^{-1}\right)$, and available macroelement content $\left(\mathrm{mg} \mathrm{dm}^{-3}\right.$ fresh soil) in the orchard nursery as measured by the Universal method in $0.03 \mathrm{~mol} \mathrm{dm}^{-3} \mathrm{CH}_{3} \mathrm{COOH}$

\begin{tabular}{lccccccccc}
\hline Soil layer $(\mathrm{cm})$ & $\mathrm{pH}_{\mathrm{H}, \mathrm{O}}$ & $\mathrm{pH}_{\mathrm{KCL}}$ & $\mathrm{EC}$ & $\mathrm{Ca}$ & $\mathrm{K}$ & $\mathrm{Mg}$ & $\mathrm{P}$ & $\mathrm{S}$ & $\mathrm{Na}$ \\
\hline $0-20$ & 6.00 & 5.25 & 250 & 777 & 56.6 & 94.4 & 3.8 & 9.1 & 12.3 \\
20-40 & 6.60 & 5.45 & 60 & 751 & 6.5 & 92.2 & 1.8 & 3.4 & 8.6 \\
Optimal range & - & $6-7$ & $0-2000$ & 1000 & $200-250$ & $60-120$ & $30-60$ & - & $<100$ \\
\hline
\end{tabular}


$1 \mathrm{~mol} \mathrm{dm}{ }^{-3} \mathrm{KCl}$ had an acid reaction and ranged from 5.25 (0-20 cm layer) to 5.45 (20-40 cm layer).

The macronutrient content of the nursery soils ranged from highly deficient for phosphorus and potassium to an optimal level for magnesium (Tab. 1). The available sulphur content in nursery soils was also above a critical limit $\left(<20 \mathrm{mg} \mathrm{S}-\mathrm{SO}_{4}\right.$ $\left.\mathrm{kg}^{-1}\right)$. We detected low (Cu, Mn, $\mathrm{Zn}$ ) or very low (B) (below the critical limit) levels for all micronutrient content in both soil layers. Fertilisation during nursery production was based on performed soil analysis and aimed to supplement the deficiencies.

In 2008 , the mean annual temperature was $9.16^{\circ} \mathrm{C}$ and it was $1.2^{\circ} \mathrm{C}$ higher than the highest mean for the years 1956-2000. The total precipitation was $530 \mathrm{~mm}$, which was $48 \mathrm{~mm}$ less than that of the last decades. Although some periods of drought were observed in May, the precipitation before the time of application of growth regulators was satisfactory (117.4 mm in July). However, lower temperatures $\left(8.5^{\circ} \mathrm{C}\right)$ were noted during 2009 . The season was extremely wet, with a total annual precipitation of $1067 \mathrm{~mm}$. Heavy rains were observed in May and July; however, the maximum precipitation was measured for June (216 mm).

\section{Statistical analysis}

The experimental data were collected and subjected to two-way analysis of variance using Statistica 9.0 software (Statsoft Inc.). The means were separated by multiplying the Duncan test at a significance level of $p=0.05$. Moreover, the Pearson productmoment correlation coefficients were calculated between the analysed parameters and considered significant for $\mathrm{p}<0.05(\mathrm{~N}=400)$.

\section{RESULTS AND DISCUSSION}

\section{'Boskoop'}

Although both of the investigated cultivars revealed strong apical dominance, they responded differently to the applied chemicals. Many studies have reported different responses of the investigated cultivars to exogenous bioregulators (Kapłan 2010). As far as the percentage of feathered 'Boskoop' trees is concerned (Tab. 2), the best results were obtained for Arbolin 036SL (81.6\%) and Arbolin Extra $(81.3 \%)$. In the first year of the study, we recorded all feathered trees where Arbolin 036SL or Arbolin Extra 038SL had been used. Lower values were noted for NeoArbolin and NeoArbolin

Table 2. The effect of NeoArbolin $\left(25.0 \mathrm{ml} \mathrm{dm}^{-3}\right)$, NeoArbolin Extra $\left(10.0 \mathrm{ml} \mathrm{dm}^{-3}\right)$, Arbolin Extra 038SL (23.7 ml $\mathrm{dm}^{-3}$ ) and Arbolin 036SL (25.0 $\left.\mathrm{ml} \mathrm{dm}^{-3}\right)$ on the growth and branching of 'Boskoop' and 'Mutsu' maiden apple trees

\begin{tabular}{|c|c|c|c|c|c|c|c|}
\hline \multirow{2}{*}{ Feature } & \multirow{2}{*}{ Treatment* } & \multicolumn{3}{|c|}{ Boskoop } & \multicolumn{3}{|c|}{ Mutsu } \\
\hline & & 2008 & 2009 & mean & 2008 & 2009 & mean \\
\hline \multirow{5}{*}{$\begin{array}{l}\text { Percentage of } \\
\text { feathered trees } \\
(\%)\end{array}$} & control & $16.3 \mathrm{~b}$ & $3.3 \mathrm{a}$ & $9.8 \mathrm{~A}$ & $1.0 \mathrm{a}$ & $0.0 \mathrm{a}$ & $0.5 \mathrm{~A}$ \\
\hline & NeoArbolin & $84.7 \mathrm{e}$ & $76.0 \mathrm{~d}$ & $80.4 \mathrm{C}$ & $90.9 \mathrm{~g}$ & $75.0 \mathrm{c}$ & $84.2 \mathrm{C}$ \\
\hline & NeoArbolin Extra & $94.7 \mathrm{f}$ & $60.0 \mathrm{c}$ & $77.4 \mathrm{~B}$ & $79.7 \mathrm{~d}$ & $99.7 \mathrm{~h}$ & $85.5 \mathrm{D}$ \\
\hline & Arbolin Extra 038SL & $100.0 \mathrm{~g}$ & $62.5 \mathrm{c}$ & $81.3 \mathrm{D}$ & $83.1 \mathrm{e}$ & $86.6 \mathrm{f}$ & $84.2 \mathrm{C}$ \\
\hline & Arbolin 036SL & $100.0 \mathrm{~g}$ & $63.3 \mathrm{c}$ & $81.6 \mathrm{D}$ & $64.7 \mathrm{~b}$ & $98.7 \mathrm{~h}$ & $74.4 \mathrm{~B}$ \\
\hline \multirow{5}{*}{$\begin{array}{l}\text { No. of feathers } \\
\text { per tree }\end{array}$} & control & $1.83 \mathrm{a}$ & $0.00 \mathrm{a}$ & $1.10 \mathrm{~A}$ & $0.00 \mathrm{a}$ & $0.00 \mathrm{a}$ & $0.00 \mathrm{~A}$ \\
\hline & NeoArbolin & $6.05 \mathrm{~b}$ & $5.50 \mathrm{~b}$ & $5.92 \mathrm{~B}$ & $7.18 \mathrm{bc}$ & $7.13 \mathrm{bc}$ & $7.16 \mathrm{~B}$ \\
\hline & NeoArbolin Extra & $8.30 \mathrm{c}$ & $5.71 \mathrm{~b}$ & $7.63 \mathrm{C}$ & $7.15 \mathrm{bc}$ & $7.88 \mathrm{c}$ & $7.36 \mathrm{~B}$ \\
\hline & Arbolin Extra 038SL & $11.10 \mathrm{~d}$ & $6.43 \mathrm{bc}$ & $9.89 \mathrm{D}$ & $7.83 \mathrm{c}$ & $6.25 \mathrm{bc}$ & $7.35 \mathrm{~B}$ \\
\hline & Arbolin 036SL & $8.60 \mathrm{c}$ & $5.57 \mathrm{~b}$ & $7.81 \mathrm{C}$ & $5.95 \mathrm{~b}$ & $7.13 \mathrm{bc}$ & $6.29 \mathrm{~B}$ \\
\hline \multirow{5}{*}{$\begin{array}{l}\text { Total length of } \\
\text { feathers } \\
\text { (cm per tree) }\end{array}$} & control & $19.8 \mathrm{ab}$ & $0.0 \mathrm{a}$ & $11.9 \mathrm{~A}$ & $0.0 \mathrm{a}$ & $0.0 \mathrm{a}$ & $0.0 \mathrm{~A}$ \\
\hline & NeoArbolin & $67.2 \mathrm{~cd}$ & $84.8 \mathrm{de}$ & $71.2 \mathrm{~B}$ & $108.7 \mathrm{bc}$ & $99.6 \mathrm{bc}$ & $104.9 \mathrm{~B}$ \\
\hline & NeoArbolin Extra & $88.9 \mathrm{de}$ & $59.3 \mathrm{~cd}$ & $81.2 \mathrm{BC}$ & $98.1 \mathrm{bc}$ & $113.0 \mathrm{c}$ & $102.3 \mathrm{~B}$ \\
\hline & Arbolin Extra 038SL & $112.0 \mathrm{e}$ & $50.3 \mathrm{bc}$ & $96.0 \mathrm{C}$ & $101.6 \mathrm{bc}$ & $87.6 \mathrm{bc}$ & $97.3 \mathrm{~B}$ \\
\hline & Arbolin 036SL & $76.6 \mathrm{~cd}$ & $46.3 \mathrm{bc}$ & $68.7 \mathrm{~B}$ & $71.5 \mathrm{~b}$ & $117.1 \mathrm{c}$ & $84.5 \mathrm{~B}$ \\
\hline \multirow{5}{*}{$\begin{array}{l}\text { Tree height } \\
(\mathrm{cm})\end{array}$} & control & $156 \mathrm{c}$ & $93 \mathrm{a}$ & $131 \mathrm{~A}$ & $160 \mathrm{~d}$ & $136 \mathrm{bc}$ & $148 \mathrm{BC}$ \\
\hline & NeoArbolin & $151 \mathrm{c}$ & $103 \mathrm{ab}$ & $140 \mathrm{~A}$ & $145 \mathrm{~cd}$ & $114 \mathrm{a}$ & $132 \mathrm{~A}$ \\
\hline & NeoArbolin Extra & $145 \mathrm{c}$ & $108 \mathrm{ab}$ & $135 \mathrm{~A}$ & $156 \mathrm{~d}$ & $127 \mathrm{abc}$ & $148 \mathrm{BC}$ \\
\hline & Arbolin Extra 038SL & $144 \mathrm{c}$ & $102 \mathrm{ab}$ & $133 \mathrm{~A}$ & $146 \mathrm{~cd}$ & $120 \mathrm{ab}$ & $138 \mathrm{AB}$ \\
\hline & Arbolin 036SL & $150 \mathrm{c}$ & $112 \mathrm{~b}$ & $140 \mathrm{~A}$ & $163 \mathrm{~d}$ & $134 \mathrm{bc}$ & $155 \mathrm{C}$ \\
\hline
\end{tabular}

*Means followed by the same letters are not significantly different at $\mathrm{p}=0.05$ 
Extra (84.7\% and $94.7 \%$, respectively). This may indicate a higher effectiveness of $\mathrm{GA}_{3}$ than $\mathrm{GA}_{4+7}$ (Arbolin 036SL vs. NeoArbolin). The higher doses of benzyladenine contained in Arbolin Extra 038SL promoted more branched trees as compared to NeoArbolin Extra. A similar effect was observed for the 'Elise' cultivar in a previous study (Gąstoł and Poniedziałek 2003). Analysing the results between the years, it should be stated that worse results were obtained in 2009. Lower temperatures as well as irradiance were recorded that year, which may have affected not only photosynthesis and consequently growth, but also the reaction to exogenous bioregulators. It also appears that 'Boskoop' could be responsive to lower rates of bioregulators than those applied in this study during more favourable climatic conditions.

Untreated 'Boskoop' trees showed almost no syllepsis (Tab. 2). The most laterals were counted in both years for Arbolin Extra (9.89 shoots per tree). In 2008 we observed more profuse branching than in 2009 (11.10 and 6.43 feathers per tree in 2008 and 2009, respectively).

The total length of feathers varied from $11.9 \mathrm{~cm}$ (control) to $96.0 \mathrm{~cm}$ (Arbolin Extra). The highest number of laterals and also the highest mean length of branches was noted in 'Boskoop' trees. NeoArbolin and NeoArbolin Extra promoted the longest laterals (12.5 and $10.4 \mathrm{~cm})$, as compared to Arbolin 036SL and Arbolin Extra (8.79 and 9.70 $\mathrm{cm}$, respectively).

The applied chemicals did not influence the trees' growth measured as their height; no differences between treatments were found except some tendencies towards weaker control tree vigour in 2009. However, the applied branching agents increased the trunk diameter of the investigated trees, measured as tree diameter above and below the graft union. Kapłan and Baryła (2006) found a differentiated vegetative growth response of apple cultivars to growth regulators. In the first season they recorded no influence, while in the second season the applied chemicals decreased the trees' vigour.

\section{'Mutsu'}

Untreated 'Mutsu' trees revealed a lack of branching potential; only $0.5 \%$ of trees were naturally feathered (Tab. 2). The highest percentage of feathered trees was observed for NeoArbolin Extra (85.5\%), followed by NeoArbolin and Arbolin Extra (both $84.2 \%$ ).
We recorded no laterals in the control maiden trees, whereas the number varied from 6.29 to 7.36 branches per tree for the treated ones. No differences between the chemicals used were found. Also, within the chemicals, the mean length of one lateral (range 13.3 to $14.4 \mathrm{~cm}$, data not shown) as well as the total length of laterals was not differentiated $(84.5$ to $104.9 \mathrm{~cm})$. The applied bioregulators drastically increased the number of side shoots. Unlike for 'Boskoop', the chemicals decreased vegetative development. Namely, NeoArbolin caused retardation in growth (132 cm, as compared to $148 \mathrm{~cm}$ for the control), and in the case of Arbolin Extra we noted 138 $\mathrm{cm}$. This effect was observed in the 2009 season. However, the terminal growth cessation may have been influenced not only directly by the chemicals, but also indirectly by the distribution of the growth capacity into a large number of sylleptic shoots. This phenomenon was reported by Hrotko et al. (1997, 2000). Arbolin Extra also diminished vegetative growth measured as the trunk diameter $10 \mathrm{~cm}$ below the graft union. However, it is worth mentioning that growth retardation did not lower the quality of the investigated trees in comparison to nursery standards in term of calliper and height specification.

The study showed the strong impact of environmental factors on the branching ability of maiden nursery trees. The role of climate conditions has been widely recognised (Wilson and Jarassamrit 1993, Tromp 1996; Lindhagen 1998, Gąstoł 2005). The experiment carried out in the first season favoured the development of lateral shoots. In contrast, with heavy rains in 2009, the percentage of properly branched trees was not as high as in 2008. This was probably not only due to lower photosynthetic activity (lower irradiance), but also was connected with a lower uptake of mineral nutrients. Even on rich soils, but with unfavourable conditions, the uptake and transport of essential elements is impaired. Although the conditions during 2009 were not beneficial for branching, the application of growth regulators was still effective.

The untreated trees of both studied cultivars demonstrated a distinct apical dominant growth habit with no lateral growth. However, their response to the application of exogenous $\mathrm{BA}+\mathrm{GA}_{3}$ and $\mathrm{BA}+\mathrm{GA}_{4+7}$ compounds differed from each other. These results are in agreement with previous reports (Jacyna 2001, Gąstoł and Poniedziałek 2003, Gąstoł 2005). Voltz et al. (1994) stated that the simultaneous application of $\mathrm{BA}$ and $\mathrm{GA}_{4+7}$ to 
nursery apple trees might in some cases suppress feather production. Other authors have expressed contrasting findings, stating that the branching effect is better if repeated (4-8 times) applications of growth regulators are used (Jarassamrit 1989, Hrotko et al. 1998, Jacyna 2001, Magyar and Hrotko 2005). However, in our study we found the effectiveness to be satisfactory after only one treatment. This is in accordance with previous reports by Kviklys (2006). During his research with several difficult to branch cultivars, high effectiveness was reported in the case of one treatment performed with Arbolin 36SL. It is especially important for nursery practice, as spraying once lowers the cost of expensive bioregulators, labour as well as decreasing environmental pollution.

The percentage of feathered trees was significantly correlated with the height of 'Boskoop' trees $(r=0.56)$ as well as with their trunk diameter $10 \mathrm{~cm}$ above the graft union $(\mathrm{r}=0.70)$. In contrast, the percentage of feathered 'Mutsu' trees was only slightly negatively correlated with their height $(r=-0.19)$. Other correlations between the measured parameters were not significant for 'Mutsu'. This also shows the different branching patterns of the investigated cultivars.

\section{CONCLUSIONS}

1. All of the investigated chemical compounds, irrespective of their composition (BA $+\mathrm{GA}_{3}$ or $\mathrm{BA}+\mathrm{GA}_{4+7}$ ) were effective in promoting laterals in the studied difficult-to-branch apple cultivars.

2. The branching effect in promoting laterals was strongly influenced by environmental factors, especially in the case of 'Boskoop' trees.

\section{REFERENCES}

ABBAs M.F., 1978. Association between branching in maiden trees and level of endogenous auxins. Acta Hort. 80: 59-62.

Basak A., Kolodziejczak P., Buban T., 1993. Paturyl 10WSC as a branching agent for young apple trees in nursery and orchards. Acta Hort. 329: 201-203.

Bielicki P., Czynczyk A., NowAkowski S., 2003. Influence of plant material quality on growth and yield of apple cultivar 'Jonagored' grafted on M.9 rootstock. Folia Hort. Suppl. 2: 143-145.

BN-178/9180-11. 1978. Soils and mineral compositions. PKN, Warsaw.

Çaglar S., Mürüvvet I., 2009. The effects of benzyladenine applications on branching of 'Mondial Gala' apple nursery trees on MM.106 in the first year growth. Kahramanmaras Sutcu Imam Univ. J. Nat. Sci. 12(1): 65-71.

EdGERTON L.J., 1983. Effects of some growth regulators on branching and flowering of young apple trees. Acta Hort. 137: 77-82.

Ferree D.C., 1981. Physiological aspects of pruning and training. In: Tree fruit growth regulators and chemical thinning. R.B. Tukey and M.W. Williams (eds), Wash. State. Univ. Coop. Ext. Serv., Pullman: 90-104.

GĄstoł M., 2005. Lateral shoot formation in apple maiden trees as influenced by different chemical compounds. Plodovodstvo, 17/2: 52-56.

Gąstoe M., Poniedziatek W., 2003. Induction of lateral branching in nursery trees. Electronic Journal of Polish Agricultural Universities, Horticulture, Volume 6, Issue 2. http://www.ejpau.media.pl.

Hrotkó K., Magyar L., Yao C., Rónay Z., 1997. Effect of repeated BA (benzyladenine) application on feathering of 'Idared' apple nursery trees. Hort. Sci. 29 (3-4): 46-51.

Hrotkó K., Magyar L., Yao C., Rónay Z., 1998. Effect of repeated BA (Benzyladnine) application on feathering of 'Idared' apple nursery trees. Acta Hort. 463: 169-176.

Hrotkó K., Magyar L., Rónay Z., 2000. Improved feathering on apple nursery trees by BA application. Acta Hort. 514(4): 113-119.

JACYNA T., 1996. Induction of lateral branching in nursery pear and apple trees with plant growth regulators. Fruit Varieties J. 50(3): 151-156.

JACYNA T., 2001. Studies on natural and chemically induced branching in temperate fruit and ornamental trees. Rozprawa habilitacyjna, AR w Lublinie: 45-66.

JARASSAMRIT N., 1989. Branch induction of spur type Red Delicious apple nursery trees. Acta Hort. 240: 155-158.

Jaumień F., Czarnecki B., Mitrut T., Poniedzialek W., 1993. Very similar effects of mixture $\mathrm{GA}_{3}+$ $\mathrm{BA}$ (6-benzyloaminopurine) and $\mathrm{GA}_{4+7}+\mathrm{BA}$ on branching on some cultivars in nursery. Acta Hort. 329: $35-42$.

Joustra M., 1989. Effect of Promalin on ornamental Malus and Prunus species. Acta Hort. 251: 377-380.

KAPŁAN M., 2010. Effect of growth regulators on the branching ability of maiden trees of the Šampion and Jonica cultivars. Folia Hort. 22(2): 3-7.

Kapean M., Baryea P., 2006. The effect of growth regulators on the quality of two-year old apple trees of Šampion and Jonica cultivars. Acta Sci. Pol. Hortorum Cultus 5(1): 79-89.

KVIKLYS D., 2006. Induction of feathering of apple planting material. Latvian J. of Agron. 9: 58-63.

Lindhagen M., 1998. Predicting branching in young apple trees (Malus domestica Borkh.). Acta Hort. 456: $125-132$.

Magyar L., HrotKó K., 2005. Effect of BA (6-benzyladenine) and $\mathrm{GA}_{4+7}$ on feathering of sweet 
cherry cultivars in the nursery. Acta Hort. 667: 417-422.

OOSTEN H.J. van, 1983. Boomkwaliteit en teelttechniek. Fruittelt 47: 1226-1229.

Rossi A.D., Rufato L., Giacobbo C.L., Gomez F.R.C., FAChinello J.C., 2004. Use of Promalin on one-year old tree of the apple cv. Catarina. Acta Hort. 636: 145-149.

Theron K.I., Steyn W.J., Jacobs G., 2000. Induction of proleptic shoot formation on pome fruit nursery trees. Acta Hort. 514: 239-244.

Tromp J., 1996. Sylleptic shoot formation in young apple trees exposed to various soil temperature and air humidity regimes in three successive periods of growing season. Ann. Bot. 77: 63-70.

Voltz R.K., Gibbs H.M., Popenoe J., 1994. Branch induction on apple maiden trees: effect of growth regulators and defoliation. New Zeal. J. Crop Hort. 22: $277-283$

Wilson S.J., JARASSAMRIT N., 1993. Nursery factors influencing lateral shoot development in a spur type apple cultivar. Sci. Hort. 56(3): 207-215.

\section{WPŁYW BIOREGULATORÓW NA \\ ROZGAŁEZZANIE DRZEWEK JABŁONI W SZKÓŁCE}

Streszczenie: Jednoroczne okulantyjabłoni(Malus domestica Borkh.): 'Boskoop'/M.9 oraz 'Mutsu'/M.9 traktowano dolistnie różnymi mieszaninami $\mathrm{BA}+$ $\mathrm{GA}_{3}$ (w dawce $450+450 \mathrm{mg} \mathrm{dm}^{-3}$ lub $780+120 \mathrm{mg}$ $\left.\mathrm{dm}^{-3}\right)$ oraz $\mathrm{BA}+\mathrm{GA}_{4+7}(450+450$ lub $330+570$ $\left.\mathrm{mg} \mathrm{dm}{ }^{-3}\right)$. Obie $\mathrm{z}$ badanych odmian wykazały silną dominację wierzchołkową, w sposób naturalny nie tworząc pędów syleptycznych. Wszystkie zastosowane preparaty wpłynęły korzystnie na indukcję, liczbę oraz długość pędów bocznych. Pojedynczy zabieg rozkrzewiania okazał się wystarczający dla uzyskania właściwej architektury koronki okulanta. Czynniki środowiskowe, w tym klimatyczne, miały ogromny wpływ na formowanie pędów bocznych, zwłaszcza w przypadku odmiany 'Boskoop'. W przypadku odmiany 'Boskoop', potwierdzono zależność pomiędzy zdolnością do tworzenia pędów syleptycznych a parametrami opisującymi wigor drzewka (wysokość okulanta, jego średnica). Dla odmiany 'Mutsu' nie stwierdzono takich zależności. Użyte regulatory wzrostu, stosowane w wysokich dawkach, koniecznych do przełamania dominacji wierzchołkowej nie wykazywały fitotoksyczności. 